\title{
Evaluační nástroje motoriky podle vývojových norem u české populace
}

\section{Evaluation motor according to development motor standards in the Czech population}

\author{
Jakub Holický, Martin Musálek
}

Fakulta tělesné výchovy a sportu, Univerzita Karlova v Praze

\begin{abstract}
Abstrakt
Výběr vhodného evaluačního nástroje při hodnoceni vývoje i úrovně motoriky představuje rozsáhlou a složitou problematiku. Cílem této studie proto bylo rozebrat a srovnat diagnostickou kvalitu tř́ nejpouživanějších nástrojů v oblasti psychomotorického vývoje dětí $i$ dospélých, které využivají vývojových norem u české populace. Jedná se o Orientační test dynamické praxe (OTDP), Movement Assessment Battery for Children-2 (MABC-2) a Test vývoje hrubé motoriky-2 (TGMD-2) s Bruininks-Oseretzky Test of Motor Proficiency-Second Edition (BOT-2) baterií, která pro české podmínky zatím standardizovaná není.

Ve srovnání s uvedenými třemi diagnostickými nástroji vykázal Bruininks-Oseretzky Test of Motor Proficiency-Second Edition (BOT-2) nepropracovanějši design struktury testů a možnost hodnocení konceptu psychomotoriky v nejširším věkovém rozpětí probandỉ. Mimo to BOT-2 dosahuje vysoké validity $i$ reliability (0,90 až 0,97). Dalši zjišsěnou výhodou je i možnost využit zkrácenou formu celé testové baterie (Short Form).

$Z$ tohoto di̊vodu se domniváme, že by se Bruininks-Oseretzky Test of Motor Proficiency-Second Edition (BOT-2) měl stát nedílnou součástí standardizovaných nástrojủ hodnotících psychomotorický vývoj v českém prostředí.
\end{abstract}

\section{Abstract}

Evaluation development of motor skills in the context of the assessment evaluation tools is very complicated issue. The aim of this study was analysis and comparison of three assessment diagnostic tools with BOT-2. The OTDP, TGMD-2 and MABC-2 are the most widespread tools for exploring of psychomotor development of children and adults with the standard norms for Czech population. Bruininks-Oseretzky Test of Motor Proficiency-Second Edition (BOT-2) batteries for Czech conditions has not been standardized yet.

The Bruininks-Oseretzky Test of Motor Proficiency-Second Edition (BOT-2) showed the best design in the test's structure in comparison to three diagnostic tools. The BOT-2 has in the psychomotor test the widest age range of probands. Besides BOT-2 achieves a high validity and reliability (0,90 to 0,97). Other advantage, which was realized, is using the short form of the test battery, called Short Form.

Because of this reasons we believe the Bruininks-Oseretzky Test of Motor Proficiency-Second Edition (BOT2) should be a part of standardized assessment tools, which evaluate the psychomotor development in the Czech environment.

Klíčová slova: evaluace, vývojové normy, psychomotorický vývoj, Bruininks-Oseretzky Test of Motor Proficiency

Key words: evaluation, development standards, psychomotor development, Bruininks-Oseretzky Test of Motor Proficiency

Studie vznikla s podporou projektu SVV 2013-267602 a v rámci programu PRVOUK č. 39 Společenskovědní aspekty zkoumání lidského těla. 


\section{ÚVOD}

Motorický vývoj v sobě obsahuje soubory změn motorického chování během růstu a dospívání, procesy, které tyto změny umožňují, a faktory, které je ovlivňují (Payne \& Isaacs, 2007). Zákonitosti vývoje motoriky probíhají v celistvosti vývoje samotného jedince - změny motorických funkcí probíhají v úzké souvislosti se změnami ostatních funkcí a s vývojem tělesným i psychickým (Goodwin \& Leech, 2003). K evaluaci vývoje motoriky lze využít celou řadu testovacích baterií, jejichž vzájemné dělení je značně rozsáhlé (Měkota \& Blahuš, 1983; Černá, 1995). Pokud se zaměříme na testovací baterie v oblasti psychomotorického vývoje jedince, kde hodnocení probíhá na základě vývojových norem, hovoříme o následujících příkladech:

- $\quad$ Motoriktest für vier- bis sechsjährige Kinder (MOT 4 - 6), (Zimmer \& Volkamer, 1987)

- $\quad$ Movement Assessment Battery for Children (M - ABC), (Henderson, Sugden, \& Barnett, 1992)

- $\quad$ Peabody Development Scales - Second Edition (PDMS-2), (Folio \& Fewell, 1983)

- $\quad$ Körperkoordinationtest für Kinder (KTK), (Kiphard \& Schilling, 1974)

- $\quad$ Test of Gross Motor Development - Second Edition (TGMD-2), (Ulrich, 2000)

- $\quad$ Bruininks-Oseretsky Test of Motor Proficiency, Second Edition (BOTMP -

BOT-2), (Bruininks, Steffens, Spiegel, \& Werder, 1989; R. H. Bruininks, 2005)

Přestože se některá specifika použití liší, základní koncept hodnocení je u všech zmíněných testů podobný (Cools, De Martelaer, Samaey, \& Andries, 2008).

Psychomotorika představuje holistický př́stup chápání ve spojení pohybu těla a psychických procesů. Umožňuje vnímání jak nálady, pocitů, tak psychické funkce, jehož zrcadlem je motorický projev jedince (Blahutková, Klenková, \& Zichová, 2005; Wise \& Bozarth, 1987).

V českých podmínkách se nejčastěji objevují čtyři psychomotorické testy, a to: Orientační test dynamické praxe (OTDP), Test vývoje hrubé motoriky-2 (TGMD-2), Movement Assessment Battery for Children - Second Edition (MABC-2) a Bruininks-Oseretzky Test of Motor Proficiency, který však nemá v České republice normy (Kohoutek \& Krkošková, 2002).

První tři testy mají české normy vytvořené nebo jsou v procesu standardizace.

\section{ORIENTAČNÍ TEST DYNAMICKÉ PRAXE (OTDP)}

Autorem OTDP je Míka, který test vytvořil v roce 1982. Orientační test dynamické praxe slouží ke zjištění úrovně hrubé a jemné motoriky a její schopnosti zareagovat na dynamický podnět u dětí předškolního věku. V prŕípadě motoricky postižených dětí jej lze použít v jakémkoli věku. Dítěti je zadán úkol, při němž má ve všem napodobovat administrátora. Test se skládá z 8 položek, zaměřených na pohyb rukou, nohou a jazyka. Administrátor nejprve daný úkon sám předvede, poté je úkolem dítěte stejný úkon co nejlépe a nejpřesněji zaznamenat. Př́i zadávání úkolů administrátor postupuje dle záznamového archu. Na základě subjektivního hodnocení examinátora se posuzuje, jak kvalitně dítě test zvládlo, nebo nezvládlo. Do záznamového archu se následně zapíše úspěšný či neúspěšný pokus. Plnění každého úkolu se sleduje přesně v sekundách (Kohoutek \& Krkošková, 2002; Měkota \& Cuberek, 2007; Čelikovský, 1990). Split-half metoda hodnocení reliability dosahovala hodnoty 0,42 (Svoboda, Krejčířová, \& Vágnerová, 2001). Vzhledem na přesné rozlišení je mnohými odborníky test považován za zbytečně podrobný, má percentilové normy, provádí se i kvalitativní vyhodnocení analýzou nesplněných položek. Je převážně využiván v České republice (Černá, 1995).

\section{TEST VÝVOJE HRUBÉ MOTORIKY-2 (TGMD-2)}

Test vývoje hrubé motoriky-2 (TGMD-2) vychází z původního testu hrubé motoriky (TGMD), který byl poprvé publikován v roce 1985 (Ulrich, 1985). Nová verze TGMD-2 pochází z roku 2000 (Ulrich, 2000). TGMD-2 je testem, který se zaměřuje na vývoj hrubé motoriky. Je využíván v kineziologii, obecné a speciální pedagogice, psychologii a fyzioterapii. Umožňuje zaměřit se na děti od 3 do 10 let. Identifikuje děti, které jsou výrazně zaostalé za svými vrstevníky v hrubém motorickém vývoji - tento motorický symptom má v literatuře své odborné jméno DCD Development Coordination Disorder (Cairney et al., 2005; Ulrich, 2000). Samotný test se zaměřuje na testování lokomočních dovedností a manuální zručnost. Výkon jedince je oznámkován bud' hodnotou jedna, pokud provedl cvičení správně, nebo hodnotou nula pokud provedl cvičení špatně. Součet bodů ukazuje konečný výsledek. Administrativa testu trvá 15 až 20 minut (Cools et al., 2008). Realibilita testu se pohybuje v rozpětí 0,83 až 0,91 (Valentini, 2012).

U testu TGMD-2 se objevuje problém v „crosskulturalní“ oblasti a u hodnocení subtestu házení přes hlavu, 
kde se objevuje př́liš specifické zaměření této dovedností (Simons \& Van Hombeeck, 2003).

Jeho standardizaci $\mathrm{v}$ českých podmínkách provádí tým ze Západočeské univerzity v Plzni pod vedením docenta Čepičky.

\section{MOVEMENT ASSESSMENT BATTERY FOR CHILDREN-2 (MABC-2)}

MABC-2 je testová baterie, která vychází ze své starší verze MABC (Henderson et al., 1992). Test MABC vycházel z testu Test of Motor Impairment (TOMI) a z původního testu Oseretsky (Burton \& Miller, 1998; Simons, 2004). Testovací baterii tvoří tři části: standardizovaná testová baterie, dotazník ("checklist") a intervenční manuál. Standardizovaná testová baterie a dotazník jsou zaměřeny na identifikaci a popis postižení motorických funkcí. Testová baterie vyžaduje přítomnost dítěte, zatímco dotazník vyplňuje dospělá osoba, která hodnotí motorické kompetence dítěte.

Baterie je rozdělena do tří věkových skupin. První je od 3 do 6 roků, druhá od 7 do 10 roků a třetí od 11 do 16 roků. Pro každou věkovou skupinu je určena sada osmi testů, které jsou rozčleněny podle tří motorických komponent: jemná motorika (manuální dovednost), hrubá motorika (míření a chytání) a rovnováha. Provedení všech osmi testů zabere 20 až 40 minut (Cools et al., 2008; Psotta, 2012). Testová baterie je založena na behaviorální metodě hodnocení motoriky (Vallaey \& Vandroemme, 1994). MABC-2 je primárně určena k identifikaci lehkých a středních motorických obtíží, pro klinický výzkum a plánování intervencí, pro hodnocení intervenčních programů a jako výzkumný nástroj (Henderson et al., 1992). Realibilita testu se pohybuje v rozpětí 0,49 až 0,70 (Visser \& Jongmans, 2004).

U testu MABC-2 nenalezneme při vyhodnocení informace o nadprůměrných výsledcích u jedinců, často je mu také vytýkán design testu pro mladší děti (Cools et al., 2008).

Jeho standardizaci v českých podmínkách provádí tým z Univerzity Palackého v Olomouci pod vedením docenta Psotty.

Poslední uvedený test Bruininks-Oseretzky Test of Motor Proficiency české normy nemá, i když řada autorů se domnívá, že ano. Např́klad podle profesor Koláře jsou jediné standardizované testy pro diagnostiku dyspraxie Movement Assessment Battery for Children (MABC) a Bruininks-Oseretsky Test of Motor Proficiency (BOTMP). Podle Svobody (2001) BOTMP patří k nejužívanějším bateriím u nás v oblasti diagnostiky mentálně postižených.

\section{BRUININKS-OSERETZKY TEST OF MOTOR PROFICIENCY - SECOND EDITION (BOT-2)}

Původní Oseretzky test byl vytvořen v roce 1923. N. I. Oseretzký, jeho autor, chtěl zjišt’ovat psychomotorické zralosti, tedy celkové úrovně motorického vývoje jak v oblasti hrubé, tak i jemné motoriky.

Novější verzí byla americká úprava testu z roku 1978, nazvaná Bruininks-Oseretzky Test of Motor Proficiency (BOTMP) (R. Bruininks, 1978). Test se u nás i v zahraničí často využíval (Flegel \& Kolobe, 2002; Siegel, Marchetti, \& Tecklin, 1991; Tan, Parker, \& Larkin, 2001; B. N. Wilson, Polatajko, Kaplan, \& Faris, 1995; Černá, 1995). Tato verze nebyla u nás nikdy standardizována.

V roce 2005 byl test po téměř 30 letech upraven na novou verzi Bruininks-Oseretzky Test of Motor Proficiency - Second Edition (BOT-2) (R. H. Bruininks, 2005). Test obsahuje několik desítek položek, rozdělených do subtestů zaměřených na koordinaci, přesnost a spojení různých pohybů. Umožňuje posoudit úroveň dílčích pohybových kompetencí jak u běžné populace, tak např́klad u specifické skupiny dětí s mentálním postižením: Hodnotí jak hrubou motoriku - pohyby ramen, trupu, nohou, tak i jemnou motoriku - pohyblivost prstů, rukou, předloktí (Wang, Long, \& Liu, 2012; Wuang, Lin, \& Su, 2009). BOT2 má také krátkou formu (Short Form), která představuje vybrané dílčí úkoly z jednotlivých subtestů tak, aby co nepřesněji popsala komplexní motoriku testovaného probanda. Krátká forma testu trvá 15-20 minut, kompletní baterie 45-60 minut. Možnost testování probandů je od 4 do 21 let (Cools et al., 2008). Realibilita testu se pohybuje v rozpětí 0,90 až 0,97 (Wuang et al., 2009). Korelace mezi krátkou a dlouhou formou testu je 0,80 (Cools et al., 2008).

Studie, které vzájemné porovnávaly vypovídací hodnotu jednotlivých testů, konstatují, že při ověřování mezi testy TGMD-2 a MBAC-2, které byly vytvořeny za účelem odhalování dětí s potencionálním syndromem dyspraxie, se prokázalo, že jejich vypovídací hodnota je stejná (Logan, Robinson, \& Getchell, 2011). Při ověřování validity mezi MBAC-2 a BOT-2 se ukázalo, že obě baterie mají stejnou vypovídací hodnotu (Wuang, Su, \& Huang, 2012), ale proti MABC-2 má BOT-2 širší věkové spektrum a předčí ostatní evaluační nástroje. 


\section{DISKUZE}

Cílem této rešerše bylo rozebrat a srovnat kvalitu tří nejpoužívanějších diagnostických nástrojů v oblasti psychomotorického vývoje dětí i dospělých, které využívají vývojových norem u české populace, mezi něž patří Orientační test dynamické praxe (OTDP), Movement Assessment Battery for Children-2 (MABC-2) a Test vývoje hrubé motoriky-2 (TGMD-2) s Bruininks-Oseretzky Test of Motor Proficiency-Second Edition (BOT-2) baterií, která zatím pro české podmínky standardizovaná není.

Po analýze diagnostické kvality jednotlivých nástrojů docházíme k názoru, že oproti uvedeným testům má BOT-2 nejširší věkové rozpětí pro testování probandů. Test umožňuje evaluaci daleko širšího spektra determinantů jako jemné, hrubé motoriky, koordinace a síly. Hlavní nevýhodou BOT-2 může být delší doba administrativy oproti jiným testů. To je z pohledu autorů Roeber, Tober, Bolt, \& Pollak (2012) kompenzováno přesností tohoto nástroje. Výsledky získané při měření s BOT-2 umožňují komparaci s výsledky zahraničních studií, např́íklad s normami Spojených států amerických, který často tento test využívají. V tabulce 1. jsou uvedeny silné a slabé stránky jednotlivých testů podle řady českých i zahraničních autorů. V tabulce 2. je přehledně znázorněno porovnání jednotlivých administrativních aspektů testů opět podle řady českých i zahraničních autorů.

Tabulka 1: Silné a slabé stránky jednotlivých testovacích nástrojů

\begin{tabular}{|l|l|l|}
\hline \multicolumn{1}{|c|}{$\begin{array}{c}\text { Testovací } \\
\text { baterie }\end{array}$} & \multicolumn{1}{|c|}{ Silné stránky } & \multicolumn{1}{c|}{ Slabé stránky } \\
\hline OTDP & $\begin{array}{l}\text { V př́padě motorického poškození } \\
\text { dítěte neomezené věkové rozpětí } \\
\text { testování }\end{array}$ & $\begin{array}{l}\text { Starý testovací nástroj } \\
\text { Subjektivní názor examinátora pro hodnocení } \\
\text { Slabá reliabilita testu }\end{array}$ \\
\hline TGMD-2 & $\begin{array}{l}\text { Věkové rozpětí pro předškolní věk } \\
\text { Vysoká reliabilta testu } \\
\text { Obsahuje kvalitativní aspekty } \\
\text { pohybového chování pro nadprůměrné } \\
\text { a podprůměrné dovednosti }\end{array}$ & $\begin{array}{l}\text { Nehodnotí jemnou motoriku a koordinaci } \\
\text { jedince }\end{array}$ \\
\hline MABC-2 & $\begin{array}{l}\text { Věkové rozpětí pro předškolní věk } \\
\text { Mezinárodní normativní data } \\
\text { Vysoká reliabilta testu }\end{array}$ & $\begin{array}{l}\text { Neobsahuje kvalitativní aspekty pohybového } \\
\text { chování pro nadprůměrné a podprůměrné } \\
\text { dovednosti } \\
\text { Nevyhovující design testu pro mladší děti }\end{array}$ \\
\hline BOT-2 & $\begin{array}{l}\text { Věkové rozpětí pro předškolní věk } \\
\text { Vysoká reliabilta testu } \\
\text { Možnost testování Short Form } \\
\text { Obsahuje kvalitativní aspekty } \\
\text { pohybového chování pro nadprůměrné } \\
\text { a podprůměrné dovednosti }\end{array}$ & $\begin{array}{l}\text { Chybí evropská normativní data } \\
\text { Komplexní test trvá až } 60 \text { minut }\end{array}$ \\
\hline
\end{tabular}


Tabulka 2: Administrativni aspekty jednotlivých testi̊

\begin{tabular}{|c|c|c|c|c|c|c|c|}
\hline $\begin{array}{c}\text { Testovací } \\
\text { baterie }\end{array}$ & Účel & Věkové & $\begin{array}{l}\text { Casová } \\
\text { náročnost } \\
\text { (min) }\end{array}$ & Vybavení & $\begin{array}{l}\text { Počet } \\
\text { testů v } \\
\text { baterii }\end{array}$ & Výsledky & $\begin{array}{c}\text { Cena (rok } \\
\text { 2013)* }\end{array}$ \\
\hline OTDP & $\begin{array}{l}\text { Identifikace } \\
\text { deficitů ve } \\
\text { vývoji jemné } \\
\text { a hrubé } \\
\text { motoriky }\end{array}$ & 4:0-6:0 & $15-25$ & $\begin{array}{l}\text { Manuál a } \\
\text { záznamový arch }\end{array}$ & 8 & $\begin{array}{l}\text { Standard } \\
\text { score }\end{array}$ & Neprodává se \\
\hline TGMD-2 & \begin{tabular}{|l|} 
Identifikace \\
dětí, které \\
zaostávají \\
proti svým \\
vrstevníkům \\
ve vývoji \\
motoriky
\end{tabular} & $3: 0-10: 0$ & $15-20$ & $\begin{array}{l}\text { Páska, } \\
\text { křída, kužele, } \\
10-15 \text { cm } \\
\text { světlý míč, } 20-25 \\
\text { cm míč, 15-20 } \\
\text { cm } \\
\text { měkký míč, } \\
\text { tenisový míček, } \\
\text { svinovací metr, } \\
\text { testovací baterii } \\
\text { TGMD-2 }\end{array}$ & 12 & $\begin{array}{l}\text { Percentily, } \\
\text { Standard } \\
\text { score, } \\
\text { věkové } \\
\text { rozpětí, } \\
\text { kvocient } \\
\text { hrubé } \\
\text { motoriky }\end{array}$ & $134 \$$ \\
\hline MABC-2 & $\begin{array}{l}\text { Identifikace } \\
\text { a popis } \\
\text { motorického } \\
\text { opoždění } \\
\text { ve vývoji } \\
\text { motoriky }\end{array}$ & $4: 0-12: 0$ & $20-30$ & $\begin{array}{l}\text { Testovací baterie } \\
\text { MABC-2, stopky }\end{array}$ & \begin{tabular}{|l}
32,4 \\
věkové \\
skupiny \\
(4×8 \\
položek)
\end{tabular} & $\begin{array}{l}\text { Percentily, } \\
\text { celkový } \\
\text { výsledek } \\
\text { poruchy } \\
\text { motoriky }\end{array}$ & $1219 \$$ \\
\hline BOT-2 & $\begin{array}{l}\text { Identifikace } \\
\text { a popis vad } \\
\text { ve vývoji } \\
\text { motoriky } \\
\text { jedince }\end{array}$ & $4: 0-21: 10$ & $\begin{array}{l}\text { SF:15-20 } \\
\text { LF: } 45-60\end{array}$ & $\begin{array}{l}\text { Testovací baterii } \\
\text { BOT-2, stopky, } \\
\text { dvě židle, stůl a } \\
\text { prostor } 18 \mathrm{~m} \times \\
18 \mathrm{~m}\end{array}$ & $\begin{array}{l}\text { SF: } 14 \\
\text { LF:53 }\end{array}$ & $\begin{array}{l}\text { Standard } \\
\text { score, } \\
\text { Scale } \\
\text { score, } \\
\text { Percentily, } \\
\text { Subtest } \\
\text { výsledky, } \\
\text { celkové } \\
\text { výsledky }\end{array}$ & $990 \$$ \\
\hline
\end{tabular}

Vysvětlivky: * cena uvedená na Pearson assessment, SF (krátká forma), LF (dlouhá forma), 4:0 (roky a měsíce)

Testy MABC-2 a TGMD-2 jsou svým rozsahem, jak v oblasti věkového rozpětí, tak časovou náročností přibližně stejné. U BOT-2 zjišt’ujeme, že svým věkovým rozsahem, počtem položek i detailností výsledků, které můžeme získat v měření, jasně převyšuje ostatní testovací baterie. I proto byla testovací baterie BOT-2 doporučována například profesorem Kolářem v rámci semináře neuromuskulárních poruch a jejich diagnostiky. U jednotlivých subtestů BOT-2 je stanovena faktorová struktura, a to dokonce i pro určité věkové kategorie, což u ostatních testovacích baterií nenalezneme (Brenda N Wilson, Kaplan, Crawford, Campbell, \& Dewey, 2000). Faktorová struktura testu je rozdělena do tř́ věkových kategorií 4-7 let, 8-11 let, 12-21 let. BOT-2 v sobě obsahu čtyři hlavní testy, kterými jsou síla, tělesná koordinace, manuální koordinace a jemná motorika. Každý $\mathrm{z}$ těchto čtyř hlavních testů obsahuje dva subtesty, mezi které patř́ jemná motorika - přesnost, jemná motorika 
- integrace, manuální zručnost, koordinace horní končetiny, bilaterální koordinace, rovnováha, rychlost a síla (Roeber et al., 2012). Rozsah tohoto testu umožňuje na rozdíl od TGMD-2 evaluaci jemné motoriky a koordinace. Dále pak BOT-2 hodnotí kvalitativní aspekty pohybového chování pro nadprůměrné i podprůměrné dovednosti, což MABC-2 neumožňuje.

BOT-2 je doporučován zahraničními autory zejména k určování motorických poruch, screening studiím, rozvoji a evaluaci pohybových tréninkových programů, tak i podpoře výzkumných šetření (Cools et al., 2008).

Z uvedených faktů a názorů jednotlivých autorů jasně vyplývá, že výhody testovací baterie BOT-2 převládají nad ostatními testovacími nástroji. Pro odbornou veřejnost zůstává tedy otázkou, proč nebyla provedena standardizace testovací baterie BOT-2.

\section{ZÁVĚR}

Problematika hodnocení motorického vývoje na základě vývojových norem je u nás i v zahraničí často diskutována. V České republice mezi nejpoužívanější nástroje v dané oblasti patří testy OTDP, TGDM-2 a MBAC-2, u kterých české normy existují, nebo se pracuje na jejich standardizaci.

V př́ípadě Bruininks-Oseretzky Test of Motor Proficiency - Second Edition (BOT-2) české normy neexistují, přestože řada studií potvrdila, že BOT-2 má vyšší vypovídací hodnotu než TGDM-2 nebo MBAC-2, vzhledem $\mathrm{k}$ propracovanější struktuře testovací baterie.

V rešerši jsme představili silné a slabé stránky všech testovacích nástrojů a dospěli k závěru, že by bylo vhodné standardizovat BOT-2 v českých podmínkách.

\section{LITERATURA}

Blahutková, M., Klenková, J., \& Zichová, D. (2005). Psychomotorické hry pro dèti s poruchami pozornosti a pro hyperaktivní dèti: Masarykova univerzita.

Bruininks, R. (1978). Bruininks-Oseretsky test of motor proficiency. Circle Pines, MN: American Guidance Service.

Bruininks, R., Steffens, K., Spiegel, A., \& Werder, J. (1989). The Bruininks-Oseretsky Test of Motor Proficiency: Development, research, and intervention strategies. Paper presented at the 2nd International Symposium Psychomotor Therapy and Adapted Physical Activity. Catholic University, Leuven, Belgium.

Bruininks, R. H. (2005). Bruininks-Oseretsky Test of Motor Proficiency, (BOT-2). Minneapolis, MN: Pearson Assessment.

Burton, A. W., \& Miller, D. E. (1998). Movement skill assessment: Human Kinetics Publishers.

Cairney, J., Hay, J. A., Faught, B. E., Wade, T. J., Corna, L., \& Flouris, A. (2005). Developmental coordination disorder, generalized self-efficacy toward physical activity, and participation in organized and free play activities. The Journal of pediatrics, 147(4), 515-520.

Cools, W., De Martelaer, K., Samaey, C., \& Andries, C. (2008). Movement skill assessment of typically developing preschool children: A review of seven movement skill assessment tools. Journal of sports science and medicine, 8, 154-168.

Čelikovský, S. (1990). Antropomotorika pro studující tělesnou výchovu. 3. vyd., Praha: Státní pedagogické nakladatelství, 1990, $288 \mathrm{~s}$.

Černá, M. (1995). Kapitoly z psychopedie. Praha: UK, 1995.

Flegel, J., \& Kolobe, T. H. (2002). Predictive validity of the Test of Infant Motor Performance as measured by the Bruininks-Oseretsky Test of Motor Proficiency at school age. Physical Therapy, 82(8), 762-771.

Folio, R., \& Fewell, R. R. (1983). Peabody Developmental Motor Scales and Activity Cards: Manual: Pro-Ed. Goodwin, L. D., \& Leech, N. L. (2003). The Meaning of Validity in the New Standards for Educational and Psychological Testing: Implications for Measurement Courses. Measurement and evaluation in Counseling and Development.

Henderson, S. E., Sugden, D. A., \& Barnett, A. L. (1992). Movement assessment battery for children: Psychological Corporation.

Kiphard, E. J., \& Schilling, F. (1974). Körperkoordinationstest für Kinder: KTK: Beltz Test.

Kohoutek, R., \& Krkošková, A. (2002). Základy užité psychologie: Akademické nakladatelství CERM.

Logan, S. W., Robinson, L. E., \& Getchell, N. (2011). The comparison of performances of preschool children on two motor assessments. Perceptual and Motor Skills, 113(3), 715-723. doi: 10.2466/03.06.25.pms.113.6.715- 
723

Měkota, K., \& Blahuš, P. (1983). Motorické testy v tělesné výchově: SPN.

Měkota, K., \& Cuberek, R. (2007). Pohybové dovednosti, činnosti, výkony. 1. vyd. Olomouc: Univerzita Palackého, 2007

Payne, V. G., \& Isaacs, L. D. (2007). Human Motor Development: A Lifespan Approach: McGraw-Hill.

Psotta, R., \& Hendl, J. (2012). The movement assessment battery for children - 2: cross-cultural comparison between 11-15 years old children from the Czech Republic and United Kingdom. Acta Universitatis Palackianae Olomucensis.

Roeber, B. J., Tober, C. L., Bolt, D. M., \& Pollak, S. D. (2012). Gross motor development in children adopted from orphanage settings. Developmental Medicine and Child Neurology, 54(6), 527-531.

Siegel, J. C., Marchetti, M., \& Tecklin, J. S. (1991). Age related balance changes in hearing-impaired children. Physical Therapy, 71(3), 183-189.

Simons, J. (2004). Introductie tot de psychomotoriek: Garant.

Simons, J., \& Van Hombeeck, C. (2003). Toepasbaarheid van de Test of Gross Motor Development, second edition. Kine varia, 39, 16-21.

Svoboda, M., Krejčířová, D., \& Vágnerová, M. (2001). Psychodiagnostika dětí a dospívajících: Portál.

Tan, S. K., Parker, H. E., \& Larkin, D. (2001). Concurrent validity of motor tests used to identify children with motor impairment. Adapted Physical Activity Quarterly.

Ulrich, A. (1985). TGMD, Test of Gross Motor Development: PRO-ED.

Ulrich, A. (2000). Test of gross motor development-2. Austin, TX: Pro-Ed.

Valentini, N. C. (2012). Validity and Reliability of the TGMD-2 for Brazilian Children. Journal of Motor Behavior, 44(4), 275-280.

Vallaey, M., \& Vandroemme, G. (1994). Psychomotoriek bij kinderen: Acco.

Visser, J., \& Jongmans, M. (2004). Extending the Movement Assessment Battery for Children to be suitable for 3 -year-olds in the Netherlands. Unpublished manuscript.

Wang, H. Y., Long, I. M., \& Liu, M. F. (2012). Relationships between task-oriented postural control and motor ability in children and adolescents with Down syndrome. Research in Developmental Disabilities, 33(6), 17921798.

Wilson, B. N., Kaplan, B. J., Crawford, S. G., Campbell, A., \& Dewey, D. (2000). Reliability and validity of a parent questionnaire on childhood motor skills. The American Journal of Occupational Therapy, 54(5), 484493.

Wilson, B. N., Polatajko, H. J., Kaplan, B. J., \& Faris, P. (1995). Use of the Bruininks-Oseretsky test of motor proficiency in occupational-therapy. American Journal of Occupational Therapy, 49(1), 8-17.

Wise, R. A., \& Bozarth, M. A. (1987). A psychomotor stimulant theory of addiction. Psychological review, 94(4), 469.

Wuang, Y. P., Lin, Y. H., \& Su, C. Y. (2009). Rasch analysis of the Bruininks-Oseretsky Test of Motor ProficiencySecond Edition in intellectual disabilities. Research in Developmental Disabilities, 30(6), 1132-1144.

Wuang, Y. P., Su, C. Y., \& Huang, M. H. (2012). Psychometric comparisons of three measures for assessing motor functions in preschoolers with intellectual disabilities. Journal of Intellectual Disability Research, 56(6), 567-578.

Zimmer, R., \& Volkamer, M. (1987). Motoriktest für vier- bis sechsjährige Kinder: Mot 4-6; Manual: BeltzTest. 